\title{
鼻アレルギーに対する $\mathrm{N}-5^{\prime}$ 錠の臨床評価
}

\begin{tabular}{|c|c|c|c|c|}
\hline 菊屋 & 義則 1 ） -二宮 & 優子1) - 原田 & 康夫 1 ) - 竹林 & 脩文 ${ }^{2}$ ) \\
\hline & 公志 ${ }^{2}$ ・ 和田 & 秀毅 ${ }^{2}$ - 岡崎 & 英登3) - 永澤 & 容 ${ }^{3}$ \\
\hline & 建夫4）・野田 & 益弘 ${ }^{5}$ ) - 宮脇 & 修二5)・小村 & 良5) \\
\hline & 首徳 6)・ & 隆司 $\left.{ }^{6}\right) \cdot$ 娄田 & 良三7) & \\
\hline
\end{tabular}

\section{Clinical Effect of $\mathrm{N}-5^{\prime}$ Tablets on Nasal Allergy}

\author{
Yoshinori Kikuya, Yuko Ninomiya and Yasuo Harada \\ (Hiroshima University) \\ Shunbun Takebayashi, Koji Sera and Hideki Wada \\ (Hiroshima Prefectural Hospital)
}

Hideto Okazaki and Yutaka Nagasawa

(Hiroshima city Asa General Hospital)

Tateo Yashiki

(Hiroshima Memorial Hospital)

Masuhiro Noda, Shuji Miyawaki and Ryo Omura

(Hiroshima Red-Cross Hospital)

Michinori Kurokawa and Takashi Yamashita

(Onomichi General Hospital)

Ryozo Yabuta

(Chugoku Rosai Hospital)

$\mathrm{N}-5$ ' tablets were given to 36 patients with nasal allergy for 4 consecutive weeks.

Subjective improvement was noted in $77.7 \%$ and over-all improvement in $80.6 \%$. The effects of this drug appeared within 1 week in $46.4 \%$, within 2 weeks in $71.4 \%$ and within 3 weeks in all patients.

In $81.3 \%$ of the patients sneezing attacks were reduced, in $76.5 \%$ nasal discharge and in $72.2 \%$ nasal obstruction. Patients with sneezing and nasal discharge had better relief of symptoms than did those with nasal obstruction.

\footnotetext{
1) 広島大学医学部耳鼻咽喉科学教室.

2) 県立広島病院耳鼻咽喉科

3 ）安佐市民病院耳鼻咽喉科

4 ) 広島記念病院耳鼻咽喉科

5 ）広島赤十字病院耳鼻咽喉科

6 ) 尾道総合病院耳鼻咽喉科

7 ) 中国労災病院耳鼻咽喉科
} 
Abdominal pain and nausea were noted in one case, but these were not severe and disappeared after medication was stopped.

Synthetic evaluation showed moderate improvement in $77.8 \%$ and great improvement in $27.8 \%$. Therefore, the authors consider that N-5' tablets can be recommended for the treatment of nasal allergy.

\section{はじめに}

I 型アレルギーの代表的疾患である鼻アレルギーは, 近年増加の傾向にある．鼻アレルギーの対 症療法としては，抗ヒスタミン剂を中心とした，いわゆる広義の抗アレルギー剂が主に使用されて きた. しかし，DSCG（インタール）の出現以後，アレルギーの発症段階に直接作用する，予防 的抗アレルギー剂が注目される様になってきた. D S C Gは, 局所投与剂であり, 消化管よりの吸 収が悪いため, 同系統の経口剂の開発が盛んに行われてきた。 その結果 $\mathrm{N}-5^{\prime}$ (Tranilast) ${ }^{1)}, \mathrm{HC}$ 20-511 (Ketotifen $)^{2)}$ ，E-0659 (azelastine hydrochloride) ${ }^{3) 4)}$ などの睞剂が開発され，鼻アレル ギーに対する有用性が確認されてきた.

今回私共は, 鼻アレルギー患者に既売のトラニラストとは剂型の異なる， N-5 $5^{\prime}$ 銫を使用する機 会を得たので, その有効性と安全性について隐㕅的検璟を行った。

\section{方}

\section{1 ）研究機関}

広島大学医学部, 徂立広島病院, 安佐市民病 院, 広島記念病院, 広島赤十字病院, 尾道総合 病院, 中国労災病院の各耳鼻咽矣科の 7 施設が この研究に参加した.

2 ) 研究期間

昭和58年 9 月から 12 月までの約 4 ケ月間に本 治験は行われた。

3 ) 対象

対象としては, 薬剂の効果判定が可能な程度 の症状を有する鼻アレルギー腎者とし，以下の 患者は原則として除外した。

(1) D S C G 使用中の患者.

(2)効果判定を妨げる鼻疾患，その他重篤な合 併症 (鼻咠, 肥厚性鼻炎, 慢性副鼻腔炎など) のある患者.

(3)肝疾患, 腎疾患, 心疾患, その他重篤な合 併症を有し，試験対象として不適と考えられる 患者.

(4)妊婦および妅娠している可能性のある患 者.

(5)減感作療法を開始して 5 ケ月以内の患者.

\section{法}

\section{4 ）薬剂の投与法およびその期間}

対照観察期間を $1 \sim 2$ 週間設け, その後, 通 常成人には $\mathrm{N}-5^{\prime}$ 銫（1 鍄中トラニラストとし て $50 \mathrm{mg}$ を含有）を 1 回 2 錠，1 日 3 回経口投与 した。小児には 1 回 1 鋜， 1 日 3 回経口投与し た。投与期間は原则として 4 週閒以上とした。

5 ) 併用薬剂

鼻症状が激しく，やむを得ない場合に限り， 抗ヒスタミン剂の頓用を行うが, D S C G, 血 管収縮剂, ヒスタグロビン，ステロイド，副交 感神経遮断剂, 気管支拡張剂, 降圧剂の併用は 原則として避けた。むし，乙れらの薬剤を併用 した場合は，その旨，治療経過表に記載するこ ととした。

6 ) 推察項目および評価才法

(1)アレルギー検査

陽性判定基準は表 1 に従い，乙れらの検査之 問診により診断した。

(2)鼻症状

鼻アレルギー日記を用い, くしゃみ発作, 鼻 汁, 鼻閉, 嗅覚異常, 日常生活の支障度につい て，表 2 にもとづき判定した。 
表 I アレルギー検査の陽性度判定基準

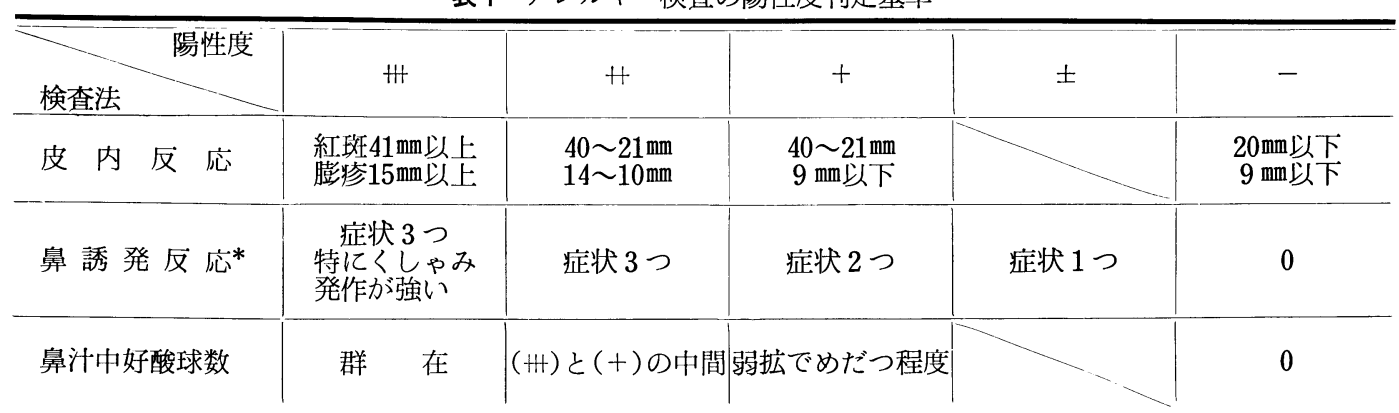

*症状 3つ：(1)くしゃみ発作・鼻瘙㾟感 (2)粘膜の腫脹蒼白 (3)水性分泌

表 2 鼻症状の程度

\begin{tabular}{|c|c|c|c|c|c|}
\hline 種 類 & Ht & H & + & \multicolumn{2}{|c|}{-} \\
\hline $\begin{array}{c}\text { くしゃみ発作 } \\
\text { (1 日の発作回数) }\end{array}$ & 10回以上 & $9 \sim 5$ 回 & 4 回以下 & & \\
\hline 鼻汁 (1 日の擤鼻回数) & 10回以上 & $9 \sim 5$ 回 & 4 回以下 & & \\
\hline 閉 & $\begin{array}{l}\text { 鼻閉が非常に強 } \\
\text { の, 口呼吸が } 1 \text { 日 } \\
\text { のちかかなりの時 } \\
\text { 間あり }\end{array}$ & $\begin{array}{l}\text { 鼻閉が強く, 口呼 } \\
\text { 吸1 } 1 \text { 日のう時 } \\
\text { 々あり }\end{array}$ & $\begin{array}{l}\text { 口呼吸は全くない } \\
\text { が鼻閉あり }\end{array}$ & な & L \\
\hline 嗅 覚 異 常 & 無 臭 & 臭うが弱い & 少し弱い & 正 & 常 \\
\hline 日常生活の支障度 & $\begin{array}{l}\text { 仕事が手につかな } \\
\text { いほど苦しい }\end{array}$ & $(+1+)$ と $(+)$ の中間 & $\begin{array}{l}\text { 仕事にはあまり差 } \\
\text { し支えない }\end{array}$ & & \\
\hline
\end{tabular}

表 3 鼻粘膜所見の程度

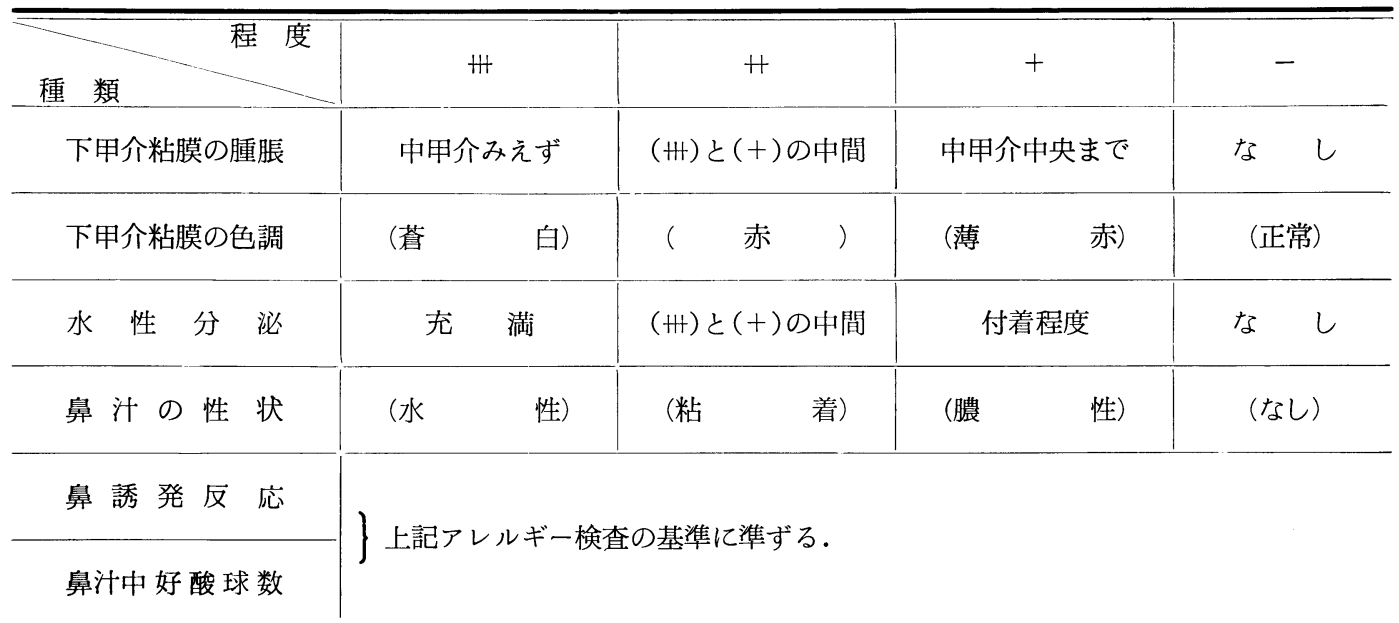


(3)鼻内所見

表 3 により, 下甲介粘膜の腫脹, 色調, 鼻汁 分泌量，鼻汁の性状について判定した。

(4)重症度打よび病型

重症度は, 鼻閉とくしゃみ発作の程度の組み 合わせより表 4 で分類した。病型は，担当医の 印象より, くしゃみ発作・鼻汁型, 鼻閉型, 鼻 閉・くしゃみ型の 3 型に分類した.

7 ) 効果判定

(1)患者の印象

薬剂投与 2 週每に，対照観察期間と比較しての 患者の印象を，大变良くなった，良くなった， 少し良くなった，かわらない，墨くなったの 5 段階で判定した。

(2)全般改善度:

対象観察期間と比較し, 武験投与期間の 2 週 毎に，著明改善，川等度改善，軽度改善，不 変, 覀化の 5 段階で判定した。

(3)効果発現時期

䧎床症状の推移により, 効果発現時期を 3 日 以内, 1 週以内, 2 週以内, 3 週以内, 4 週以 内, 8 週以内, 8 週以上，なし，不明の 9 段階 で判定した.

(4)症状, 所見別改善度

鼻アレルギー日记より，くしゃみ発作，鼻 汁, 鼻閉, 日常生活の支障度, 鼻内所見より下

\section{結}

\section{1 ) 症例の背景}

総例36例で, 性別は男子14例, 女子22例であ った．年令分布は最低 7 才，最高 64 才で，平均 年令は29.0才であった。

病型別では, くしゃみ発作・鼻汁型17例, 鼻 閉型10例，舅閉・くしゃみ型 9 例であった。全 般的重症度別では, 重症14例, 中等症20例, 軽 症 2 例であった。羅患年数では, 最低 7 ケ月, 最高 25 年で, 平均 4.5 年であった。

アレルギー家族歴あり 12 例 $(33.3 \%) ，$ アレ ルギー既応歷あり 5 例 $(13.9 \%)$ ， アレルギー 疾患の合併あり 4 例 (11.1\%) で, 現在減感作
鼻甲介腫脹，鼻汁分泌量をとりあげ，それぞれ の項目別に著効, 有効, 無効の 3 段階で判定し た. 更に, $(+): 1$ 点, (H) : 2 点, (H) : 3 点のスコアを与え， 1 週間毎に個々の項目の推 移を, くしゃみ発作・鼻汁型と鼻閉型で比較し た.

\section{(5)総合評価}

投与後に対照钼察期間と比較し, 著効, 有 効, やや有効, 不変, 悪化の 5 段階で判定し た.

\section{8 ) 副作用（安全性）}

副作用の発現した場合は，その種類，程度， 発現時划，持続日数，処置などについて记載し た。また陵床検查については，投与前後の成績 を䛉載した。

表 4 重症度の判定基準

\begin{tabular}{|c|c|c|c|c|c|}
\hline \multirow{2}{*}{\multicolumn{2}{|c|}{ 程度および重症度 }} & \multicolumn{4}{|c|}{ くしゃみ発作 } \\
\hline & & HW & H & + & - \\
\hline \multirow{2}{*}{ 鼻 } & H & 重 & 重 & 重 & 重 \\
\hline & H & 重 & 中 & 中 & 中 \\
\hline \multirow{2}{*}{ 閉 } & + & 重 & 中 & 軽 & 軽 \\
\hline & - & 重 & 中 & 軽 & 無 \\
\hline
\end{tabular}

重: 重症, 中：中等症, 軽: 軽症, 無 : 無症状

(極軽症)

\section{果}

療法継続中の症例は10例（27.8\%）であった。 原因抗原では，H Dが72. $2 \%$ と大多数を占めて いた。

\section{2 ）患者の印象}

梖剂投与. 2 週後， 4 週後の患者の印象を表 5 に示した。投与 2 週後では，大变良くなった 7 例 $(19.4 \%)$ ，良くなった 7 例 $(19.4 \%)$ ，少し 良くなった 11 例 $(30.6 \%)$ ，変わらない11例 (30.6\%)，悪くなったなし であった。投与 4 週後では，大変良くなった12例 $(33.3 \%)$ ，良 くなった12例（33.3\%)，少し良くなった 4 例 $(11.1 \%)$, 変わらない 8 例 $(22.2 \%)$, 墨くな 
ったなし であり，4 週後の改善率な，良くな った以上 $66.7 \%$ ，少し良くなった以上77. 8\%で あり，自覚的に改善を認めた症例のうち $85.7 \%$ が良くなった以上であった。

3 ）全般的改善度

楽剂投与. 2 週後， 4 週後の全般改善度は表 6 の如くである。

投与 2 週後では, 著明改善 5 例 (13.9\%), 中等度败善 9 例 $(25.0 \%)$ ，軽度改羓 8 例 $(22.2 \%)$, 不変14例 $(38.9 \%)$, 墨化なしで あった。 4 週後では，著明改善 9 例 (25.0\%), 中等度改善 14 例 $(38.9 \%)$, 軽度改善 6 例

(16.7\%), 不変 7 例 $(19.4 \%)$, 悪化なしで, 中等度改善以上 $63.9 \%$, 蛒度改善以上 $80.6 \%$ で あった。

\section{4 ) 効果発現時期}

総例36例のうち効果が認められた症例は, 28 例であった。効果発晛時期は， 3 日以内 2 例 (7.1\%)，1 週以内 11 例（39.3\%), 2 週以内 7 例 $(25.0 \%) ， 3$ 週以内 8 例 $(28.6 \%$ であ
り，全例 3 週以内に效果発現が悡められた。

5 ) 症状・所見别改善度

自觉症状および他覚的所思の改善度を表 7 ・ 8 亿示した。自覚症状の改善率は，くしゃみ発 作:81.3\%（26例/32例)，鼻汁 $76.5 \% （ 26$ 例 $/ 34$ 例)，鼻閉 $72.2 \%$ (26例/36例）で，日常生活の 支障度は $63.9 \%$ （23例/36例）であった。乙れ をくしゃみ発作・・鼻汁型（以下 S R 型と略す） と鼻閉型：鼻閉型十鼻閉・くしゃみ型（以下 $\mathrm{O}$ 型と略す）で比較してみると， S R 型では全て の症状で高い有効率が得られているのに対し て，O型ではくしゃみ発作 $73.3 \%$ ，鼻汁 64.7 $\%$, 鼻㴊 $50.0 \%$, 日常生活の支障度 $47.4 \%$ 之有 効率の低下が涊められた。他覚的所尘では，下 甲介腫胀 $60.0 \%$, 鼻汁分泌旦 $61.8 \%$ の有効率で あったが， S R 型と $\mathrm{O}$ 型では，自覚症状と同棣 にO型で荠しく有効率が低い倾问が認められ た。舅汒川好酸球数は14例中11例，78.6\%に改 缮が涊められた。

侗々の項目についての薬剂投与前後のスコア

表 5 患者の印象

\begin{tabular}{|c|c|c|c|c|c|c|c|c|}
\hline \multirow{2}{*}{$\begin{array}{l}\text { 判 } \\
\text { 定 } \\
\text { 時 } \\
\text { 期 }\end{array}$} & \multirow{2}{*}{$\begin{array}{l}\text { な大 } \\
\text { つ変 } \\
\text { た良 } \\
\text { く }\end{array}$} & \multirow{2}{*}{$\begin{array}{c}\text { た良 } \\
\text { な } \\
\text { つ }\end{array}$} & \multirow{2}{*}{$\begin{array}{l}\text { な少 } \\
\text { つし } \\
\text { た良 } \\
く\end{array}$} & \multirow{2}{*}{$\begin{array}{c}\text { 変 } \\
\text { お } \\
ら \\
\text { な }\end{array}$} & \multirow{2}{*}{$\begin{array}{c}\text { た覀 } \\
\text { な } \\
\text { な } \\
\text { つ }\end{array}$} & \multirow{2}{*}{ 計 } & 改 & 率 \\
\hline & & & & & & & 良くなった以上 & $\begin{array}{l}\text { 少し良くな } \\
\text { った以 }\end{array}$ \\
\hline 2 週 & $\begin{array}{c}7 \\
(19.4)\end{array}$ & $\begin{array}{c}7 \\
(19.4)\end{array}$ & $\begin{array}{c}11 \\
(30.6)\end{array}$ & $\begin{array}{c}11 \\
(30.6)\end{array}$ & 0 & 36 & $\begin{array}{l}14 \\
(38.9)\end{array}$ & $\begin{array}{l}25 \\
(69.4)\end{array}$ \\
\hline 4 週 & $\begin{array}{c}12 \\
(33.3)\end{array}$ & $\begin{array}{c}12 \\
(33.3)\end{array}$ & $\begin{array}{c}4 \\
(11.1)\end{array}$ & $\begin{array}{c}8 \\
(22.2)\end{array}$ & 0 & 36 & $\begin{array}{l}24 \\
(66.7)\end{array}$ & $\begin{array}{l}28 \\
(77.8)\end{array}$ \\
\hline
\end{tabular}

表 6 全般改善度

\begin{tabular}{|c|c|c|c|c|c|c|c|c|}
\hline $\begin{array}{l}\text { 判 } \\
\text { 定 }\end{array}$ & $\begin{array}{l}\text { 著 } \\
\text { 型 }\end{array}$ & $\begin{array}{l}\text { 中 } \\
\text { 等 }\end{array}$ & $\begin{array}{l}\text { 軽 } \\
\text { 度 }\end{array}$ & & & \multirow{2}{*}{ 計 } & 改 & 率 \\
\hline $\begin{array}{l}\text { 時 } \\
\text { 期 }\end{array}$ & $\begin{array}{l}\text { 改 } \\
\text { 善 }\end{array}$ & $\begin{array}{l}\text { 希 } \\
\text { 善 }\end{array}$ & $\begin{array}{l}\text { 改 } \\
\text { 善 }\end{array}$ & 変 & 化 & & 中等度改善以上 & 軽度改善以上 \\
\hline 2 週 & $\begin{array}{c}5 \\
(13.9)\end{array}$ & $\begin{array}{c}9 \\
(25.0)\end{array}$ & $\begin{array}{c}8 \\
(22.2)\end{array}$ & $\begin{array}{c}14 \\
(38.9)\end{array}$ & 0 & 36 & $\begin{array}{l}14 \\
(38.9)\end{array}$ & $\begin{array}{l}22 \\
(61.1)\end{array}$ \\
\hline 4 週 & $\begin{array}{c}9 \\
(25.0)\end{array}$ & $\begin{array}{c}14 \\
(38.9)\end{array}$ & $\begin{array}{c}6 \\
(16.7)\end{array}$ & $\begin{array}{c}7 \\
(19.4)\end{array}$ & 0 & 36 & $\begin{array}{l}23 \\
(63.9)\end{array}$ & $\begin{array}{l}29 \\
(80.6)\end{array}$ \\
\hline
\end{tabular}


平均の推移は, 図 $1 \sim 6$ の如くであった。 くし やみ発作と鼻汁では， S R 型のスコアが $\mathrm{O}$ 型よ り薬剂投与前にかなり高值であるため, 改善率 では S R 型がまさっているものの， 2 週後，4 週後のスコアは，両型共，ほぼ同じ值となって いた。しかし，鼻閉と日常生活の支障度では， $\mathrm{S} \mathrm{R}$ 型と $\mathrm{O}$ 型のスコア痓は，楽剤投与前僅かで あったが，投与後㳊非常に大きくなっていた。 他覚的所見においてもほぼ同様の絬果であり， $\mathrm{S} \mathrm{R}$ 型の下甲介腫脹は順調に改善しているのに 比べて， O型では一将軽快しているものの, 再
増悪する傾向も認められた。乙れらの結果よ り，自覚的にも他覚的にも $\mathrm{O}$ 型では，鼻閉の改 善率が S R 型より明らかに低いことが判明し た。 そしてての点が， $\mathrm{O}$ 型の日常生活の支障度 の改善率の低下に, 最も影響している点と思わ れた。

\section{6 ) 総合辣価}

重症度别，病型別および全体の総合呯価は表 9 の如くであった。全体では著効 $27.8 \%$, 有効 $38.9 \%$ ，やや有效 $11.1 \%$, 不変 $22.2 \%$ あり, 有効以上 $66.7 \%$, やや有効以上 $77.8 \%$ あっ

表 7 自覚症状の改善度

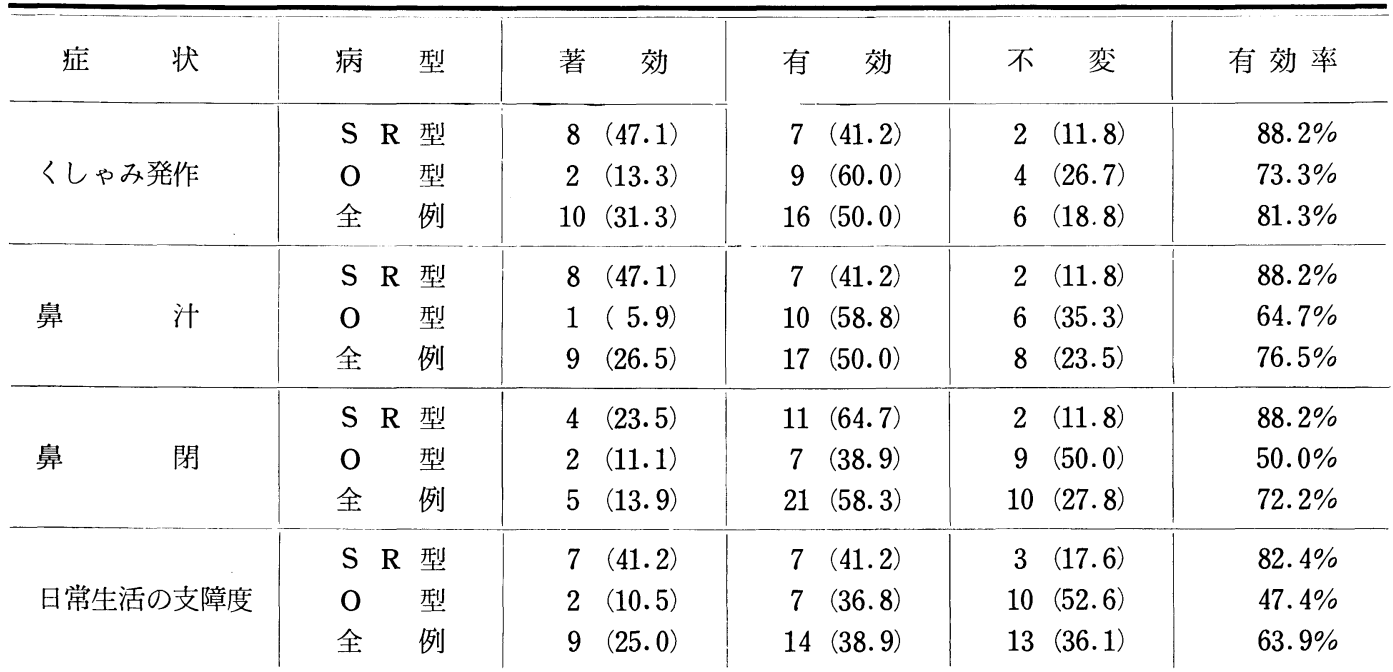

（）：\%，S R 型：くしゃみ発作・鼻汁型， O 型：鼻閉型+鼻閉・くしゃみ型

表 8 他覚的所見の改善度

\begin{tabular}{|c|c|c|c|c|c|}
\hline 見 & 病 型 & 著 & 有 効 & 不 変 & 有効率 \\
\hline 下甲介腫脹 & $\begin{array}{lll}\mathrm{S} & \mathrm{R} & \text { 型 } \\
\mathrm{O} & & \text { 型 } \\
\text { 全 } & & \text { 例 }\end{array}$ & $\begin{array}{cc}8 & (50.0) \\
3 & (15.8) \\
11 & (31.4)\end{array}$ & $\begin{array}{cc}4 & (25.0) \\
6 & (31.6) \\
10 & (28.6)\end{array}$ & $\begin{array}{cc}4 & (25.0) \\
10 & (52.6) \\
14 & (40.0)\end{array}$ & $\begin{array}{l}75.0 \% \\
47.4 \% \\
60.0 \%\end{array}$ \\
\hline 鼻汁分泌量 & $\begin{array}{lll}\mathrm{S} & \mathrm{R} & \text { 型 } \\
\mathrm{O} & & \text { 型 } \\
\text { 全 } & & \text { 例 }\end{array}$ & $\begin{array}{ll}6 & (35.3) \\
2 & (11.8) \\
8 & (23.5)\end{array}$ & $\begin{array}{cc}8 & (47.1) \\
5 & (29.4) \\
13 & (38.2)\end{array}$ & $\begin{array}{cc}3 & (17.6) \\
10 & (58.8) \\
13 & (38.2)\end{array}$ & $\begin{array}{l}82.4 \% \\
41.2 \% \\
61.8 \%\end{array}$ \\
\hline 鼻汁中好酸球数 & 全 例 & $4 \quad(28.6)$ & $7 \quad(50.0)$ & $3 \quad(21.4)$ & $78.6 \%$ \\
\hline
\end{tabular}

（）：\%，S R型：くしゃみ発作・鼻汁型， $\mathrm{O}$ 型：鼻閉型+鼻閉・くしゃみ型 


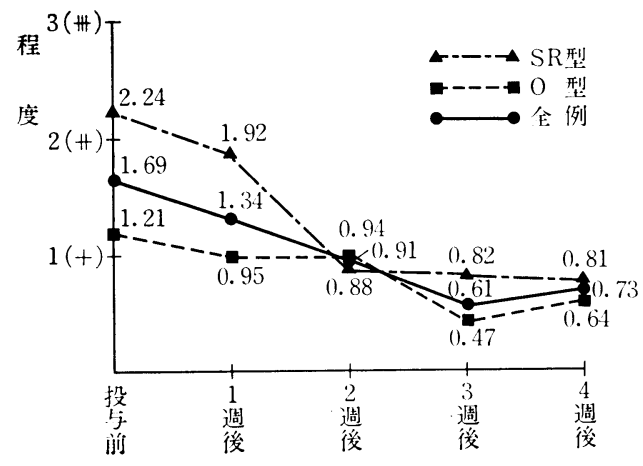

図1くしゃみ発作

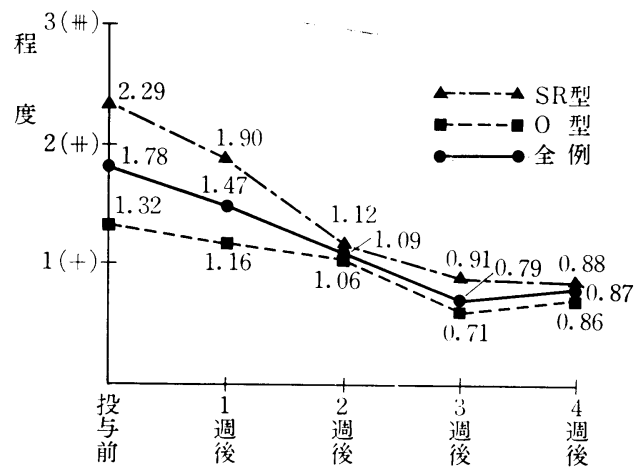

図 2 鼻汁

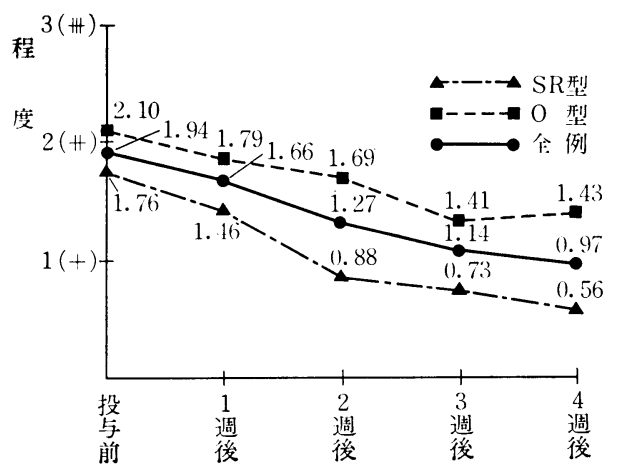

図 3 鼻 閉

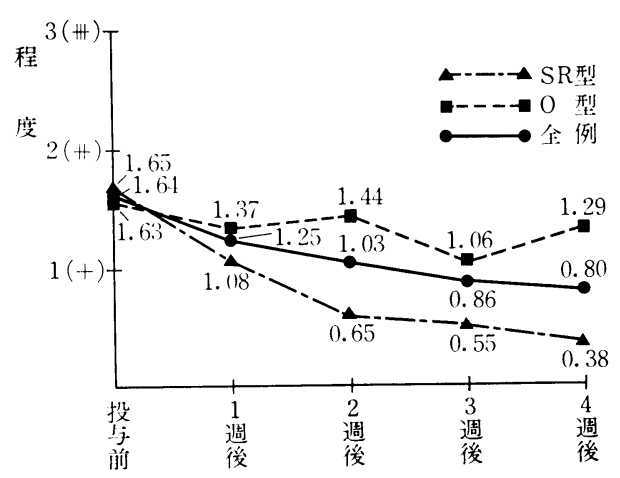

図 4 日常生活の支障度

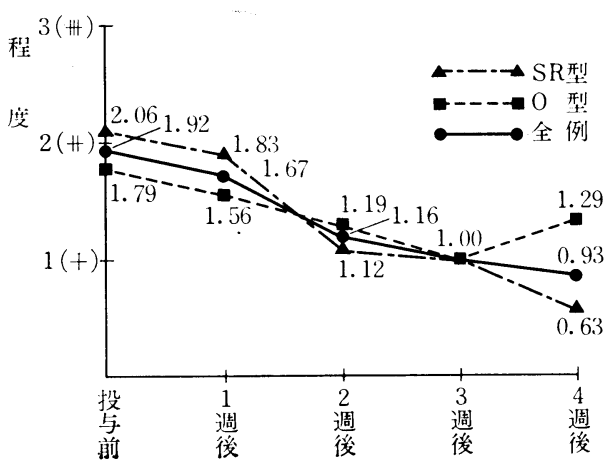

図 5 下甲介の腫脹

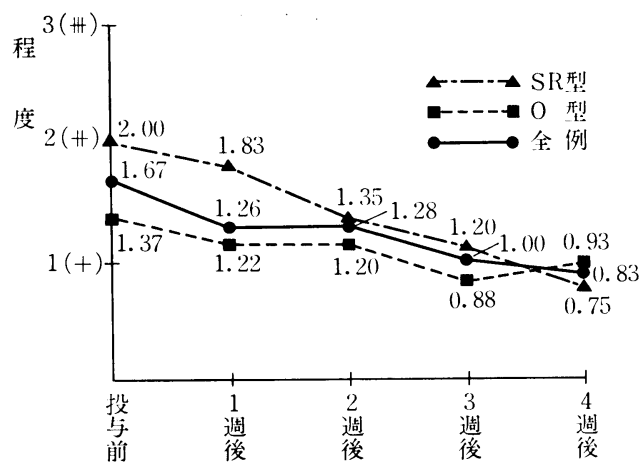

図 6 鼻汁分泌量 
た。重症度別では，重症例14例中 7 例が著効で あり，重症例の方が有効率が高かった。 また病 型別では，S R型の方が $\mathrm{O}$ 型に比して明らかに 有効例が多かった。

7 ) 副作用
36例中 1 例 $(2.8 \%)$ に腹痛之呕気が認めら れたが，重篤な副作用は全く認められなかっ た。また投与前後の血液検査や尿検查を施行で きた症例において，異常値が出現したものは一 例もなかった。

表 9 総合評価

\begin{tabular}{|c|c|c|c|c|c|c|c|c|c|}
\hline & & & p & & & \multirow{2}{*}{ 計 } & \multicolumn{2}{|c|}{ 効 } \\
\hline & & 効 & 効 & 㤫 & 変 & 化 & & 有効以上 & $\begin{array}{l}\text { や } \\
\text { 有効以上 }\end{array}$ \\
\hline 重 & 症 & $\begin{array}{c}7 \\
(50.0)\end{array}$ & $\begin{array}{c}4 \\
(28.6)\end{array}$ & $\begin{array}{c}2 \\
(14.3)\end{array}$ & $\left(\begin{array}{c}1 \\
(7.1)\end{array}\right.$ & 0 & 14 & $\begin{array}{c}11 \\
(78.6)\end{array}$ & $\begin{array}{c}13 \\
(92.9)\end{array}$ \\
\hline 度 & 中等症 & $\begin{array}{c}3 \\
(15.0)\end{array}$ & $\begin{array}{c}9 \\
(45.0)\end{array}$ & $\begin{array}{c}2 \\
(10.0)\end{array}$ & $\begin{array}{c}6 \\
(30.0)\end{array}$ & 0 & 20 & $\begin{array}{c}12 \\
(60.0)\end{array}$ & $\begin{array}{r}14 \\
(70.0)\end{array}$ \\
\hline 病 & $\mathrm{S} R$ 型 & $\begin{array}{c}9 \\
(52.9)\end{array}$ & $\begin{array}{c}6 \\
(35.3)\end{array}$ & $\begin{array}{c}1 \\
(5.9)\end{array}$ & $\begin{array}{c}1 \\
(5.9)\end{array}$ & 0 & 17 & $\begin{array}{r}15 \\
(88.2)\end{array}$ & $\begin{array}{r}16 \\
(94.1)\end{array}$ \\
\hline 型 & $\mathrm{O}$ & $\begin{array}{c}1 \\
(5.3)\end{array}$ & $\begin{array}{c}8 \\
(42.1)\end{array}$ & $\begin{array}{c}3 \\
(15.8)\end{array}$ & $(36.8)$ & 0 & 19 & $\begin{array}{c}9 \\
(47.4)\end{array}$ & $\begin{array}{c}12 \\
(63.2)\end{array}$ \\
\hline & 計 & $\begin{array}{r}10 \\
(27.8)\end{array}$ & $\begin{array}{r}14 \\
(38.9)\end{array}$ & $\begin{array}{c}4 \\
(11.1)\end{array}$ & $\begin{array}{c}8 \\
(22.2)\end{array}$ & 0 & 36 & $\begin{array}{r}24 \\
(66.7)\end{array}$ & $\begin{array}{r}28 \\
(77.8)\end{array}$ \\
\hline
\end{tabular}

( ) $: \%$

考

$\mathrm{N}-5^{\prime}$ は，国内で開発された経口的な肥満細 胞安定剂であり，現在まで気管支喘息 ${ }^{516)}$ ， ア トピー性皮膚炎 ${ }^{7)}$ ，鼻アレルギー ${ }^{11}$ 亿対する二 重盲検比較試験が行なわれ，その有用性が確認 されている.

今回私共は,より内服しやすい剤型をとの要 望に対して，N-5 錠を用いて臨床試験を行な ったが，カプセル剂や細粒剂とほぼ同程度の有 効率を得たものとの印象を得た ${ }^{118) 99}$.

本剂の効果発現は， 1 週以内 $46.4 \% ， 2$ 週以 内 $71.4 \%$ と比較的早期より認められ， 2 週以内 に全く症状が消失した症例屯 5 例 (13.9\%) 認 められた。

自覚症状では, くしゃみ発作 $81.3 \%$, 鼻汁 $76.5 \%$ ，鼻閉72.2\%で，鼻閉が最屯低值である ものの, かなり高い改善率が認められた。

他覚的所見では，下甲介腫脹 $60.0 \%$, 鼻汁分 泌量61.8\% と他剂同様自覚症状よりやや低い傾 向が認められた。しかし, 鼻汁中好酸球数は
察

78. $6 \%$ と良好な改善率が得られた。

今回, $\mathrm{S} \mathrm{R}$ 型と $\mathrm{O}$ 型に分類し, 両型の各症状 の改善率とスコアの推移を比較してみたが， $\mathrm{S}$ $\mathrm{R}$ 型とO 型では明らかな差が認められた。 $\mathrm{S} R$ 型の自覚症状の改善率は全で $80 \%$ 台で, 非常に 良好であったが，O型では鼻閉 $50.0 \%$ S R 型 に比して低值であったため, 全体としての改善 率はやや低下した。更にスコアの推移において は, 鼻閉で両型の改善率の差が最も顕著であ り，乙の点が日常生活の支障度に影響を与えて いるように思われた。現在まで $\mathrm{N}-5^{\prime}$ 之同系の 薬剂においても，数多くの臨床評価がなされて きているが，病型別の改善率についての詳しい 報告がなく，此較検討をするてとはできなかっ た.しかし，今回の検討により $\mathrm{S} \mathrm{R}$ 型とO型に おいて，明らかな差が認められたてとより，今 後はこの㥞な点にも注意を要する必要があるよ うに思われた。

総合評価では，有効以上 $66.7 \%$, やや有効以 
上77. $8 \%$ であったが，著効が $27.8 \%$ と高率であ り，重症例の $50 \%$ が著効であったととなどよ り, 鼻アレルギーの治療楽として, 非常に有効
な楽剂と思われた。また副作用は一例に消化器 症状が認められたのみであり，有効性ととも に, 安全性屯高い薬剂之思われた。

\section{ま と め}

鼻アレルギー患者 36 例に $\mathrm{N}-5^{\prime}$ 錠を投与し, 以下の結果を得た。

1 ）患者の印象は，良くなった以上 $66.7 \%$ ，少し良くなった以上 $77.8 \%$ あったた全般的改善度 では, 中等度改善以上 $63.9 \%$, 軽度改善以上 $80.6 \%$ で, 患者の印象之ほぼ一致した。

2 ) 効果発現は, 1 週以内 $46.4 \%, 2$ 週以内 $71.4 \%$ で, 全例 3 週以内に効果が認められた.

3 ）自覚症状の改善率は，くしゃみ発作 $81.3 \%$, 鼻汁 $76.5 \%$, 鼻閉 $72.2 \%$ あったが, くしゃみ 発作・鼻汁型は鼻閉型より良好な結果が得られた。

4 ）副作用は，一例に腹痛と呕気が認められたのみであった.

5 ) 総合評価では, 有効以上 $66.7 \%$, やや有効以上 $77.8 \%$ であり, 重症例の $50 \%$ が著効であっ た.

\section{文}

1) 奥田 稔，他：通年性鼻アレルギーに対するN$5^{\prime}$ の臨床評価. 一多施設群間比較二重盲検法に上 万検討一. 耳展 $26: 211 \sim 250,1983$.

2) 奥田 稔, 他：通年性鼻アレルギーに対する $\mathrm{HC}$ 20-511 (Ketotifen) と Clemastine fumarate との二重盲検比較試験による臨床的検討. 耳展 $26: 347 \sim 384,1983$.

3）奥田 稔，他：通年性番アレルギーに対するE一 0659, Disodium Cromoglicate およびプラセボ との二重旨検法による臨床的検討. 耳展 26 ： 563 605, 1983.

4) 奥田 稔, 他: 経口抗アレルギー殽 E-0659 (azelastine hydrochloride) の鼻アレルギーに 対する臨床的検討. 一 plasebo との二重肓検群間 比較試験一. 耳展 $26: 606 \sim 645,1983$.

5 ）山村雄一, 他: 気管支喘息における $\mathrm{N}-5^{\prime}$ の薬剤 評価。一多施設二重盲検法に上る検討一。医学の
献

あゆみ $108: 252 〜 273,1979$.

6 ）塩田浩政，他：N-5' の小児気管支喘息に対する 薬効検定. 一多施設二重盲検法に上る一. 小児科 臨床 $31: 2514 \sim 2526,1978$.

7 ）吉田彦太郎，他：アトピー性皮䖉炎に対するN$5^{\prime}$ の臨床評価. 一多施設二重盲検法による検討一. 西日本皮膚科 $45: 621 \sim 637,1983$.

8 ）石川和光, 他: アントラニル 酸誘導体 $\mathrm{N}-5^{\prime}$

(Rizaben) に上る小児鼻アレルギーの治療. 耳 展 $26: 133 \sim 140,1983$.

9 ) 馬場駿吉, 他: 鼻アレルギーに対する N-5'

(Rizaben) の臨床使用経 験. 耳鼻臨床 76 ： 3281 3290, 1983.

$$
\left.\begin{array}{l}
\text { 原稿到着: 昭和 } 59 \text { 年 } 4 \text { 月 } 14 \text { 日 } \\
\text { 別刷請求先: 菊屋義則 } \\
\text { T734 広島市南区霞 } 1-2-3 \\
\text { 広島大学医学部耳鼻咽喉科学教室 }
\end{array}\right)
$$

